\title{
Article \\ Cesium Doping for Performance Improvement of Lead(II)-acetate-Based Perovskite Solar Cells
}

\author{
Min-Seok Han ${ }^{1}$, Zhihai Liu ${ }^{2}$, Xuewen Liu ${ }^{1}$, Jinho Yoon ${ }^{1}$ (D) and Eun-Cheol Lee ${ }^{1,3, *(D)}$ \\ 1 Department of Nano Science and Technology, Graduate School, Gachon University, Gyeonggi 13120, Korea; \\ hanminsuk7@naver.com (M.-S.H.); arelaII5960@gmail.com (X.L.); wlsgh9838@naver.com (J.Y.) \\ 2 School of Opto-Electronic Information Science and Technology, Yantai University, Yantai 264005, China; \\ zhliu@ytu.edu.cn \\ 3 Department of Physics, Gachon University, Gyeonggi 13120, Korea \\ * Correspondence: eclee@gachon.ac.kr; Tel.: +82-31-750-8752; Fax: +82-31-750-8769
}

check for

updates

Citation: Han, M.-S.; Liu, Z.; Liu, X.; Yoon, J.; Lee, E.-C. Cesium Doping for Performance Improvement of Lead(II)-acetate-Based Perovskite Solar Cells. Materials 2021, 14, 363. https://doi.org/10.3390/ma14020363

Received: 12 December 2020 Accepted: 11 January 2021 Published: 13 January 2021

Publisher's Note: MDPI stays neutral with regard to jurisdictional clai$\mathrm{ms}$ in published maps and institutional affiliations.

Copyright: (C) 2021 by the authors. Licensee MDPI, Basel, Switzerland. This article is an open access article distributed under the terms and conditions of the Creative Commons Attribution (CC BY) license (https:// creativecommons.org/licenses/by/ $4.0 /)$.

\begin{abstract}
Lead(II)-acetate $\left(\mathrm{Pb}(\mathrm{Ac})_{2}\right)$ is a promising lead source for the preparation of organolead trihalide perovskite materials, which avoids the use of inconvenient anti-solvent treatment. In this study, we investigated the effect of cesium doping on the performance of $\mathrm{Pb}(\mathrm{Ac})_{2}$-based perovskite solar cells (PSCs). We demonstrate that the quality of the $\mathrm{CH}_{3} \mathrm{NH}_{3} \mathrm{PbI}_{3}$ perovskite film was improved with increased crystallinity and reduced pinholes by doping the perovskite with $5 \mathrm{~mol} \%$ cesium. As a result, the power conversion efficiency (PCE) of the PSCs was improved from $14.1 \%$ to $15.57 \%$ (on average), which was mainly induced by the significant enhancements in short-circuit current density and fill factor. A PCE of $18.02 \%$ was achieved for the champion device of cesium-doped $\mathrm{Pb}(\mathrm{Ac})_{2}$-based PSCs with negligible hysteresis and a stable output. Our results indicate that cesium doping is an effective approach for improving the performance of $\mathrm{Pb}(\mathrm{Ac})_{2}$-based PSCs.
\end{abstract}

Keywords: perovskite solar cells; performance improvement; lead acetate; cesium doping

\section{Introduction}

Organometallic halide perovskites $\left(\mathrm{APbX}_{3}\right.$, in which $\mathrm{A}=$ methylammonium $\left(\mathrm{MA}^{+}\right)$ or formamidinium $\left(\mathrm{FA}^{+}\right)$, and $\mathrm{X}=\mathrm{Cl}^{-}, \mathrm{Br}^{-}$, or $\mathrm{I}^{-}$) have attracted considerable attention because of their tunable bandgap, high light absorption coefficient, and long exciton diffusion length over one micrometer [1]. Since being first reported by Kojima et al. in 2009 [2], perovskite solar cells (PSCs) have been intensively investigated, with rapid improvement in power conversion efficiency (PCE) to above 25.5\% [3-8]. As a result, PSCs are considered one of the most promising candidates for next-generation solar energy devices.

To prepare a $\mathrm{CH}_{3} \mathrm{NH}_{3} \mathrm{PbI}_{3}$ perovskite, typically lead iodide $\left(\mathrm{PbI}_{2}\right)$ is used as the lead source, which chemically reacts with methylammonium iodide (MAI) at a molar ratio of 1:1 [9]. However, in order to obtain a high-quality perovskite film with a uniform morphology, an anti-solvent treatment is needed for the one-step spin-coating process [10]. This anti-solvent treatment requires expensive technology for the stable crystallization of the perovskite grains, which is detrimental to commercialization [11]. To overcome this problem, lead chloride $\left(\mathrm{PbCl}_{2}\right)$ can be employed to replace $\mathrm{PbI}_{2}$ as the lead source, which has resulted in PSCs with similar performance to those prepared from $\mathrm{PbI}_{2}$ [12]. However, to fully remove the residual $\mathrm{MACl}$ from the perovskite film, a lengthy thermal annealing process (of about two hours) is required, which consumes a large amount of energy [13]. Besides lead halides, lead acetate $\left(\mathrm{Pb}(\mathrm{Ac})_{2}\right)$ is another important lead source, which can avoid the need for the inconvenient anti-solvent treatment and lengthy thermal annealing processes [13]. Zhang and coworkers have shown that the $\mathrm{Pb}(\mathrm{Ac})_{2}$-processed $\mathrm{CH}_{3} \mathrm{NH}_{3} \mathrm{PbI}_{3}$ perovskite shows a more uniform and compact morphology with increased crystallinity, compared with $\mathrm{PbCl}_{2}$ - or $\mathrm{PbI}_{2}$-processed perovskites. As a result, the PSCs based on 
$\mathrm{Pb}(\mathrm{Ac})_{2}$-processed perovskite films were shown to exhibit a high PCE of $14.7 \%$, which is higher than that of either $\mathrm{PbCl}_{2}$ - or $\mathrm{PbI}_{2}$-based PSCs [13]. To improve the performance of PSCs, morphology control of the perovskite film is crucial, because it is strongly related to the charge generation and dissociation properties of the PSCs [14]. Solvent engineering is a widely used technique for controlling the morphology of perovskite films. For example, the use of additional dimethyl-sulfoxide has resulted in an improved film morphology of $\mathrm{Pb}(\mathrm{Ac})_{2}$-based perovskite [15]. Doping of the perovskite crystal is another effective way to improve the morphology of the perovskite films. For example, $\mathrm{Br}^{-}$and $\mathrm{FA}^{+}$have been used to partially replace $\mathrm{I}^{-}$and $\mathrm{MA}^{+}$in the perovskite structure for preparing mix-cation perovskite $\left(\mathrm{FA}_{\mathrm{x}} \mathrm{MA}_{1-\mathrm{x}} \mathrm{PbI}_{\mathrm{y}} \mathrm{Br}_{3-\mathrm{y}}\right)$, which resulted in a significantly improved $\mathrm{PCE}$ and enhanced stability of the PSCs [16]. For $\mathrm{PbI}_{2}$-processed perovskite, cesium doping into the MA site has been demonstrated to be an efficient way to improve the performance of the associated PSCs [16]. M. Saliba and coworkers have demonstrated that doping with $5 \mathrm{~mol} \%$ cesium resulted in a uniform and compact perovskite film morphology with fewer pinholes, which significantly improved the PCE of the PSCs from 16.37 to $19.20 \%$ [16]. However, there has not been any investigation into the cesium doping effect on the film morphology of $\mathrm{Pb}(\mathrm{Ac})_{2}$-based perovskite and the performance of $\mathrm{Pb}(\mathrm{Ac})_{2}$-based PSCs. Considering the importance and convenience of using $\mathrm{Pb}(\mathrm{Ac})_{2}$ for perovskite preparation, it is crucial to dope $\mathrm{Pb}(\mathrm{Ac})_{2}$-based perovskite with cesium for PSC fabrication.

In this work, we doped the $\mathrm{Pb}(\mathrm{Ac})_{2}$-based perovskite with cesium by adding a small amount of cesium iodide (CsI) into the perovskite precursor. After doping, the perovskite film showed a uniform morphology with enhanced crystallinity and reduced pinholes, which is beneficial for charge transportation. Consequently, the champion device PCE raised from 15.22 to $18.02 \%$ with negligible hysteresis and a stable output which is a significant improvement in open-circuit voltage $\left(\mathrm{V}_{\mathrm{oc}}\right)$, short-circuit current density $\left(\mathrm{J}_{\mathrm{sc}}\right)$, and fill factor (FF) via cesium doping. Additionally, the average $\mathrm{PCE}$ of the $\mathrm{Pb}(\mathrm{Ac})_{2}$-based PSCs was significantly improved from 14.1 to $15.57 \%$. Our results demonstrate the superior effect of cesium doping on the performance improvement of $\mathrm{Pb}(\mathrm{Ac})_{2}$-based PSCs.

\section{Materials and Methods}

\subsection{Materials}

Poly(3,4-ethylenedioxythiophene) polystyrene sulfonate (PEDOT:PSS, P AI 4083) was bought from Heraeus Co. (Hanau, Germany). 6,6-phenyl C61-butyric acid methyl ester (PCBM) was purchased from Nano-C Inc. (Westwood, MA, USA). 2,9-dimethyl-4,7diphenyl-1,10-phenanthroline (BCP) was obtained from Xi'an Polymer Light Technology Corp (Xi'an, China). CsI was purchased from Sigma Aldrich (St. Louis, MO, USA). Methylammonium Iodide (MAI) was provided by Great Cell Solar (Queanbeyan, Australia). $\mathrm{Pb}(\mathrm{Ac})_{2}$ was provided by Tokyo Chemical Industry (Tokyo, Japan).

\subsection{Device Fabrication}

Firstly, we cleaned patterned indium tin oxide (ITO)-glass substrates sequentially in detergent, acetone, and 2-propanol for $15 \mathrm{~min}$. The hole transport material, PEDOT:PSS, was deposited on the ITO-glass substrates through a spin-coating process and then annealed at $140{ }^{\circ} \mathrm{C}$ for $15 \mathrm{~min}$ in air. The perovskite precursors were made by mixing $\mathrm{Pb}(\mathrm{Ac})_{2}$ and MAI in $1 \mathrm{M}$ dimethylformamide. Then, the perovskite precursor with $x \mathrm{~mol} \%$ cesium, where $x=0,2.5,5.0,7.5$, or 10.0, was spin-coated on the ITO/PEDOT:PSS substrates at a rotation speed of $4000 \mathrm{rpm}$, which was followed by annealing at $80^{\circ} \mathrm{C}$ for $10 \mathrm{~min}$. The electron transport layer (ETL) was formed by spin-coating of $\mathrm{PC}_{61} \mathrm{BM}\left(30 \mathrm{mg} \cdot \mathrm{ml}^{-1}\right.$ in Chlorobenzene) on the perovskite layer at $2000 \mathrm{rpm}$ for $30 \mathrm{~s}$. For better charge transport, we deposited a BCP layer onto the ETL by spin-coating BCP solution $\left(0.5 \mathrm{mg} \cdot \mathrm{ml}^{-1}\right.$ in 2-propanol) at $450 \mathrm{rpm}$ for $30 \mathrm{~s}$. Finally, the deposition of an $80 \mathrm{~nm}$ silver electrode was achieved with thermal evaporation under a high vacuum of approximately $10^{-6}$ Torr. The device area was determined by the overlapped rectangle between the ITO and Ag electrode bars, being $0.06 \mathrm{~cm}^{2}(0.2 \mathrm{~cm} \times 0.3 \mathrm{~cm})$. 


\subsection{Measurements}

X-ray diffraction (XRD) and X-ray photoelectron spectroscopy (XPS) were conducted for the perovskite samples using the D8 Advance X-ray diffractometer (Bruker, Billerica, MA, USA) and the K-Alpha X-ray photoelectron spectrometer (Thermo Electron, Waltham, MA, USA), respectively.

Current density-voltage (J-V) curves of the PSCs were obtained using the 2400 Series $J-V$ Source Meter (Keithley Instrument, Solon, OH, USA) under an irradiation intensity of $100 \mathrm{~mW} \mathrm{~cm}{ }^{2}$ (AM1.5). We used a solar simulator (XES-301S, SAN-EI ELECTRIC, Osaka, Japan) for simulating sunlight irradiation.

The space charge limited current (SCLC) of a hole-only device (glass/ITO/PTAA/ Perovskite/PTAA/Ag) was obtained using the Keithley 2400 Source Meter under dark conditions. Electrochemical impedance spectroscopy (EIS) of the PSCs was performed with an electrochemical work station (CH instruments, Austin, TX, USA) under dark conditions. Steady-state photoluminescence (PL) spectroscopy was conducted using FLS920 (Edinburgh Instruments, Livingston, UK) at wavelengths between $720 \mathrm{~nm}$ and $800 \mathrm{~nm}$ with the excitation wavelength of $514 \mathrm{~nm}$. Ultraviolet-visible absorption spectroscopy was performed with a UV-vis-NIR 3600 spectrometer (Shimadzu, Kyoto, Japan). The morphology of the devices was measured by the scanning electron microscope (SEM, JOEL, Tokyo, Japan) and atomic force microscope (AFM, Veeco, Plainview, NY, USA).

\section{Results}

Figure 1a shows the schematic of the PSCs with a standard inverted structure of ITO/PEDOT:PSS/Perovskite/PCBM/BCP/Ag. The $\mathrm{Pb}(\mathrm{Ac})_{2}$-processed perovskite films (with and without cesium doping) were sandwiched between a poly(3,4- ethylenedioxythiophene) polystyrene sulfonate (PEDOT:PSS) hole transport layer and a 6,6-phenyl-C61butyric acid methyl ester $\left(\mathrm{PC}_{61} \mathrm{BM}\right)$ electron transport layer. The J-V curves of the PSCs with $0-7.5 \mathrm{~mol} \%$ cesium doping are exhibited in Figure $1 \mathrm{~b}$, with the photovoltaic parameters listed in Table 1. The reference PSCs without cesium doping had an average PCE of $14.1 \%$, which is a standard value for $\mathrm{Pb}(\mathrm{Ac})_{2}$-processed inverted PSCs. When the perovskite was doped with $2.5 \mathrm{~mol} \%$ cesium, the PCE increased to $15.04 \%$. With $5 \mathrm{~mol} \%$ cesium doping, the PCE further increased to $15.57 \%$, which was mainly induced by the significant improvements in $\mathrm{J}_{\mathrm{sc}}$ (from 20.16 to $21.08 \mathrm{~mA} \mathrm{~cm}^{-2}$ ) and FF (from 0.69 to 0.75 ). Doping with $7.5 \mathrm{~mol} \%$ cesium degraded the PCE to $15.37 \%$, indicating that $5 \%$ is the optimum cesium doping concentration for maximizing the PCE. As shown in Figure S1, we measured the $\mathrm{J}-\mathrm{V}$ curves scanned in the reverse and forward directions at a scan rate of $200 \mathrm{mV} \mathrm{s}^{-1}$. The $\mathrm{J}-\mathrm{V}$ curve of the reverse scan was almost the same as that of forward scan, indicating a negligible hysteresis of the device. To investigate the hysteresis deeply, dynamic J-V scans with calculation of the hysteresis index [17] are required, which is beyond the scope of this study.

(a)

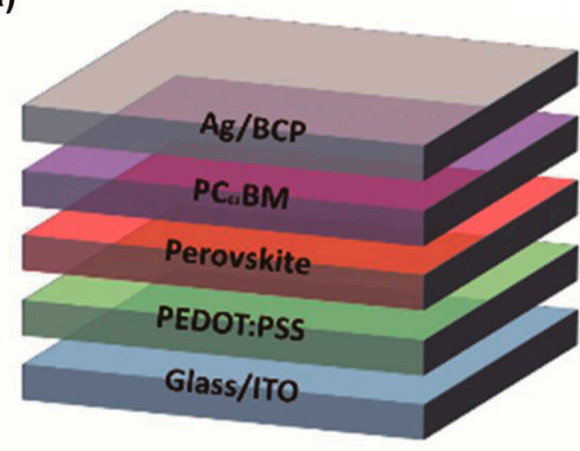

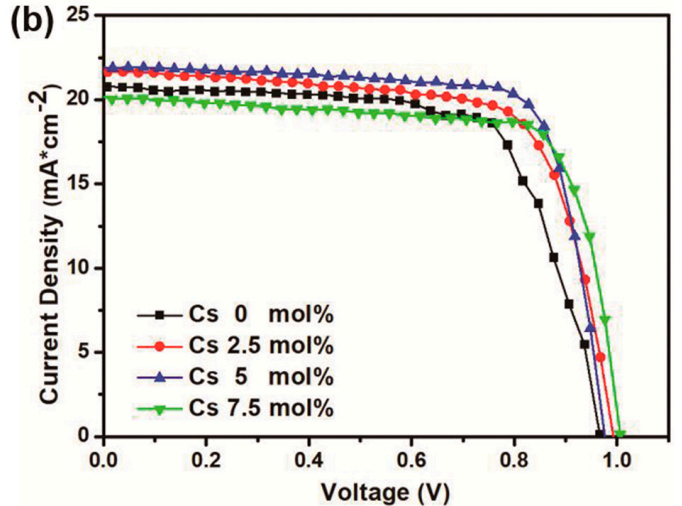

Figure 1. (a) Perovskite solar cell structure. (b) Current density-voltage (J-V) characteristics of the MAPbI3 PSCs with different cesium doping concentration. 
Table 1. Average photovoltaic parameters of the $\mathrm{MAPbI}_{3}$ PSCs based on perovskite precursors with $0 \mathrm{~mol} \%, 2.5 \mathrm{~mol} \%, 5.0 \mathrm{~mol} \%$, and $7.5 \mathrm{~mol} \%$ cesium doping.

\begin{tabular}{ccccc}
\hline $\begin{array}{c}\text { Cesium Doping Concentration } \\
\text { (mol\%) }\end{array}$ & $\mathbf{V}_{\mathbf{~ o c}}(\mathbf{V})$ & $\mathbf{J}_{\mathbf{s c}}\left(\mathbf{m A ~ c m} \mathbf{~ c m}^{-\mathbf{2}}\right)$ & FF (\%) & PCE (\%) \\
\hline 0 & 0.97 & 20.16 & 69 & 14.10 \\
2.5 & 0.98 & 21.84 & 71 & 15.04 \\
5 & 0.98 & 21.08 & 75 & 15.57 \\
7.5 & 1.01 & 20.8 & 75 & 15.37 \\
\hline
\end{tabular}

To identify the origin of the improved PCE by cesium doping, we investigated the morphology of the $5 \%$-Cs-doped and undoped perovskite films. As is evident in the surface SEM images in Figure 2a, the undoped perovskite film had poor surface coverage with many pinholes. A perovskite layer processed from a $\mathrm{Pb}(\mathrm{Ac})_{2}$-based precursor showed a similar surface morphology with some flaws, which might be caused by MA and halide deficiencies as shown in [13]. Figure 2a,d show that with increasing cesium doping concentration, the coverage of the perovskite layer onto PEDOT:PSS increased. As shown in Figure 2c, the $5 \mathrm{~mol} \%$-cesium-doped perovskite film had a dense and uniform morphology with full surface coverage. AFM images, shown in Figure S2, further confirm the increased surface uniformity with cesium doping; the root mean square roughness of the cesiumdoped perovskite film is $8.6 \mathrm{~nm}$, which is much lower than that of the pristine perovskite $(14.6 \mathrm{~nm})$. Furthermore, we found that the cesium-doped perovskite film showed less lateral grain boundaries compared to the pristine perovskite film. As discussed in previous studies, the pinholes in the perovskite film trap carriers, which further increase the charge recombination in the PSCs [18]. The SEM and AFM measurements indicate an improved morphology of the perovskite film upon cesium doping, which explains the PCE improvement, where improved perovskite seeding may be induced by the cesium addition [16]. These seeds might later turn into nucleation sites for further growth of perovskite during crystallization, which results in denser grains [16]. A similar process was found by Li et al. where MAI-modified PbS nanoparticles behaved as growth seeds for highly compact perovskite films [19]. To prove this mechanism, we characterized the crystallinity of the pristine and cesium-doped perovskite films.
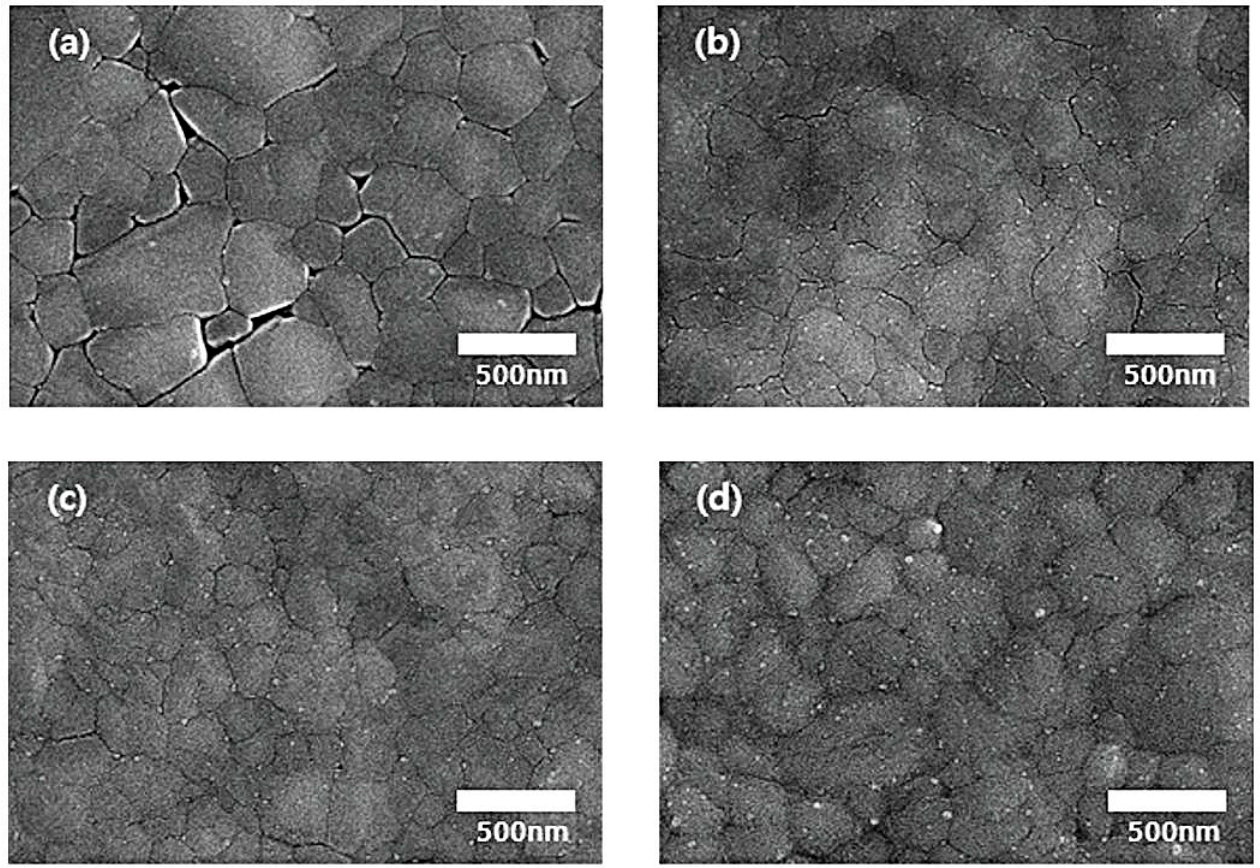

Figure 2. Top-view SEM images of perovskite films with (a) 0, (b) 2.5, (c) 5, and (d) 7.5 mol\% cesium doping concentration. 
Figure 3a compares the XRD spectra of the cesium-doped and pristine perovskite films. All peaks in the XRD patterns show the presence of the $\mathrm{CH} 3 \mathrm{NH} 3 \mathrm{PbI} 3$ tetragonal crystal structure [20]. It can be seen that the intensity of the (110) peak at $14^{\circ}$ of the cesiumdoped perovskite film is higher than that of the undoped one. Moreover, the peak at about $12^{\circ}$, which relates to the (001) lattice planes of hexagonal $\mathrm{PbI}_{2}$, is dramatically reduced with cesium doping. This indicates that the decomposition of the perovskite to $\mathrm{PbI}_{2}$ was suppressed by cesium doping [21,22]. In the UV-vis light absorption (Figure $3 b$ ), a small blue shift can be observed with cesium doping, indicating a slightly increased optical bandgap, in good agreement with previous studies [23].

(a)

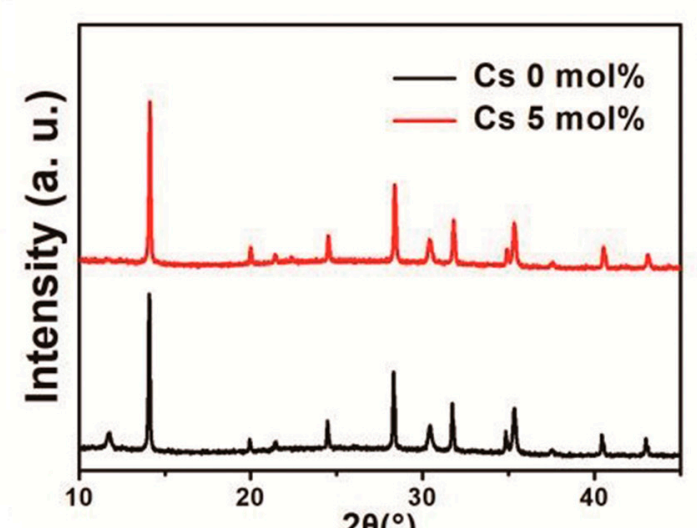

(c)

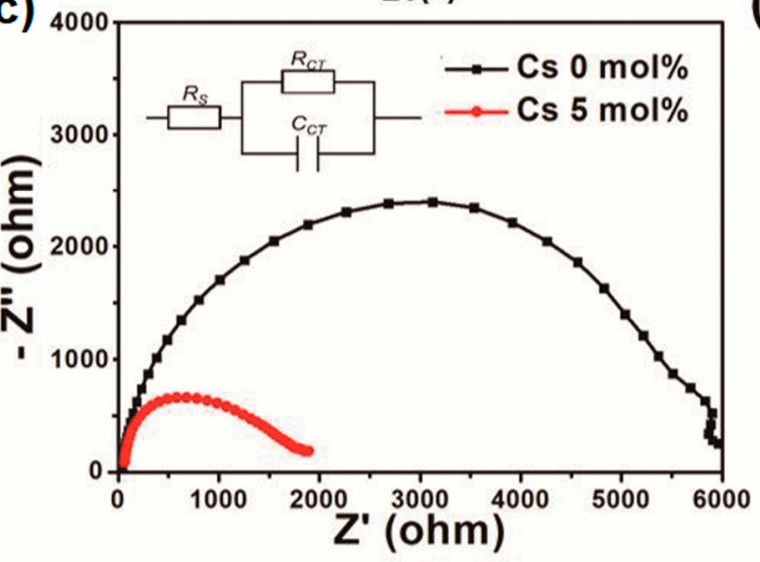

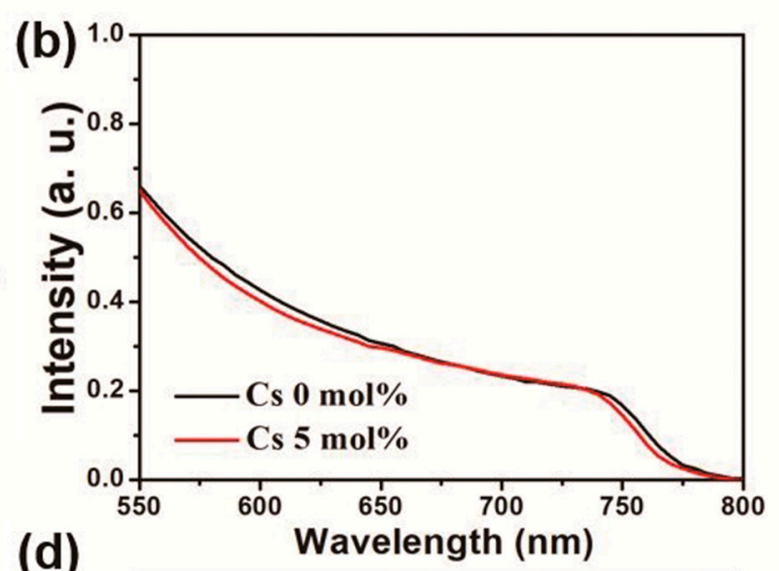

(d)

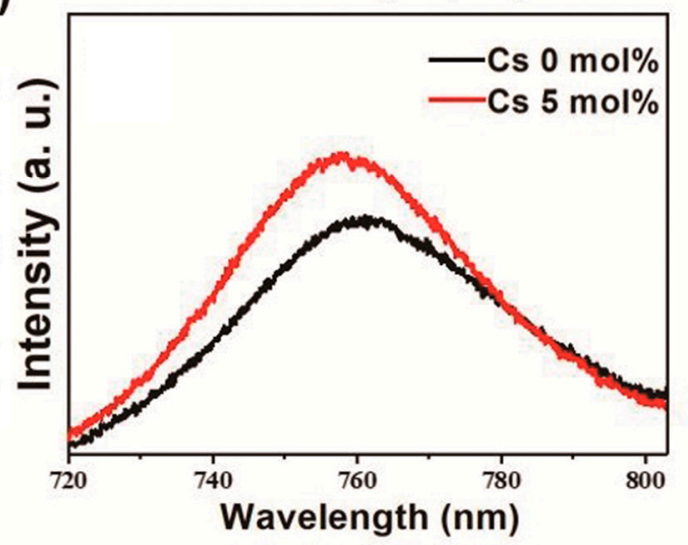

Figure 3. (a) XRD patterns. (b) Ultraviolet-visible absorption spectra of the perovskite films with different cesium doping concentrations. (c) Nyquist plots of the PSCs without and with 5\% cesium doping with a bias of 0.8 V. (d) Photoluminescence (PL) spectra of the perovskite films without and with $5 \mathrm{~mol} \%$ cesium doping.

We also conducted EIS for the PSCs under one sun illumination to obtain the resistance information upon cesium doping. Figure $3 \mathrm{c}$ shows the Nyquist plots that are fitted with the equivalent circuit, which is shown in the inset. After fitting, the series resistance $\left(R_{s}\right)$, charge recombination resistance $\left(R_{c t}\right)$, and chemical capacitance $\left(C_{c t}\right)$ of the films could be obtained and the values of them are listed in Table $S 1$. The $\mathrm{R}_{\mathrm{s}}$ value for the case with $5 \mathrm{~mol} \% \mathrm{Cs}(60.5 \Omega)$ is $33.0 \%$ lower than that without Cs doping $(90.3 \Omega)$, which contributes to the enhancement of $\mathrm{J}_{\mathrm{sc}}$ and FF. The $\mathrm{C}_{\mathrm{ct}}$ values, which are associated with the densities of space charges at the interfaces, are similar for the cases with and without $5 \%$ Cs doping $\left(2.9 \times 10^{-9} \mathrm{~F}\right.$ and $3.0 \times 10^{-9} \mathrm{~F}$, respectively). The $R_{c t}$ of $5 \%$ Cs-doped sample $(3198 \Omega)$ is lower than that of undoped sample $(6653 \Omega)$. Because the lower $R_{c t}$ indicates the larger electron recombination at the interfaces, the $R_{c t}$ values predict the higher leakage current and the lower $\mathrm{J}_{\mathrm{sc}}$ for the $\mathrm{Cs}$-doped samples. However, our experimental results show that the doping of $5 \%$ Cs reduces the leakage current, as explained below, and increases the $\mathrm{J}_{\mathrm{sc}}$ (see Figure $4 \mathrm{~b}$ ). The experimental results of previous studies are also controversial; some studies reported that $\mathrm{J}_{\mathrm{sc}}$ increases with $\mathrm{R}_{\mathrm{ct}}$ [24-26], while other studies reported the increase in $R_{c t}$ reduced $J_{s c}$ [27-29]. We speculate that $R_{c t}$ in our circuit model may not 
correctly represent the recombination resistance; $R_{c t}$ in the circuit model was extracted from a high frequency impedance semicircle, whereas some previous studies insisted that $R_{c t}$ is related to both high and low frequency semicircles [30-32]. Further studies using more sophisticated circuit models are required to obtain the more accurate $R_{\mathrm{ct}}$. Figure $3 \mathrm{~d}$ shows the PL spectra for the $5 \mathrm{~mol} \%$-Cs-doped and undoped perovskite films on glass substrates. Evidently, the PL peak of the cesium-doped perovskite film was slightly blueshifted to $756 \mathrm{~nm}$ (the PL peak of the pristine perovskite film is at $760 \mathrm{~nm}$ ), which is consistent with the UV-vis absorption results in Figure 3d. The intensity of the PL peak of the cesium-doped perovskite film is $24 \%$ higher than that of the pristine perovskite film, which indicates decreased surface-trap states (related to non-radiative PL recombination) and increased perovskite crystallinity (consistent with the SEM results) [33].

(a)

(c)
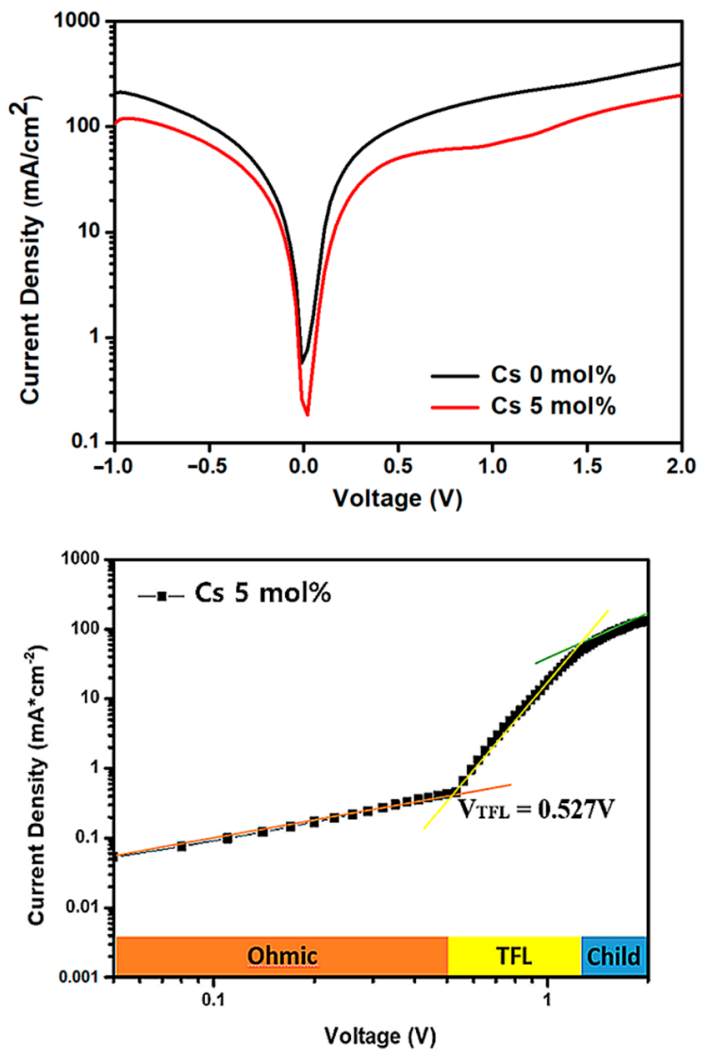

(b)

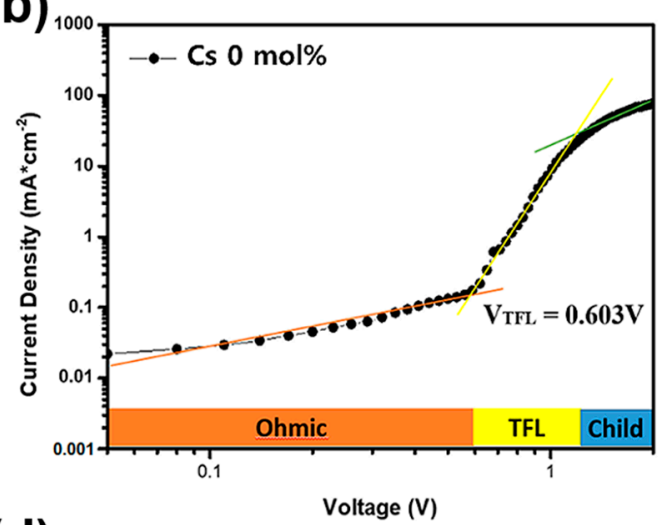

(d)

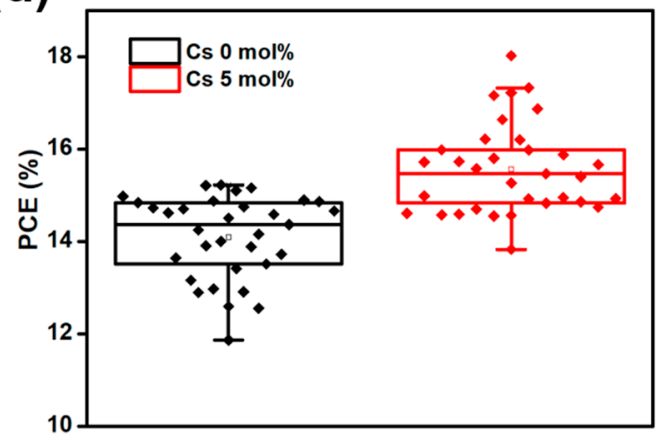

Figure 4. (a) Dark J-V characteristics of the PSCs with and without $5 \mathrm{~mol} \%$ cesium doping. SCLC of the PSCs (b) without and (c) with cesium doping. (d) PCE distribution box chart of the PSCs without and with 5\% cesium doping.

Figure 4a showed the dark J-V characteristics of the $5 \mathrm{~mol} \%$-Cs-doped and undoped PSCs. The cesium-doped PSC shows smaller leakage current than the reference PSC without cesium doping across the voltage range 0 to $-1.0 \mathrm{~V}$. To analyze the trap density of the perovskite films with cesium doping, we measured the SCLC of the hole-only devices described above $[34,35]$. As shown in Figure $4 b, c$, the $J-V$ curve can be divided into three regions.

The first segment at low bias $(<0.4 \mathrm{~V})$ is the ohmic region, in which the current density shows the almost linear increase with the voltage [36]. The second segment is called the trap-filled limit (TFL) region, in which the current density has rapid nonlinear growth, indicating the TFL in which the injected carriers deactivate available trap states [36]. At high voltages, the current density increases slowly, which is referred to as the Child's regime. 
The TFL voltage $\left(V_{T F L}\right)$ is the voltage where the ohmic and TFL current curves intersect. The trap density $\left(n_{\text {trap }}\right)$ can be calculated from $\mathrm{V}_{\mathrm{TFL}}$ using the following equation [37];

$$
V_{T F L}=\frac{e n_{\text {trap }} L^{2}}{2 \epsilon_{0} \epsilon}
$$

where $L$ is the perovskite film thickness, $\epsilon(\approx 5.7565)$ is the relative dielectric constant of the $\mathrm{CH}_{3} \mathrm{NH}_{3} \mathrm{PbI}_{3}$ perovskite film [38], $\epsilon_{0}$ is the vacuum permittivity, and $e$ is the elementary charge. As a result, the $n_{\text {trap }}$ values of the undoped and $5 \mathrm{~mol} \%$-Cs-doped devices are $5.8 \times 10^{16} \mathrm{~cm}^{-3}$ and $3.6 \times 10^{16} \mathrm{~cm}^{-3}$, respectively. The reduced trap density in the cesiumdoped sample can be explained by the reduced pinholes and improved crystallinity of the perovskite layers (shown in Figure 2). In Figure 4d, it is shown that adding $5 \mathrm{~mol} \%$ cesium enhanced the average PCE.

XPS spectra for the $5 \mathrm{~mol} \%$ cesium-doped perovskite film (Figure $5 \mathrm{a}$ ) show the Cs $3 \mathrm{~d}_{5 / 2}$ peak at $724.41 \mathrm{eV}$, confirming the presence of cesium in the sample. In Figure $5 \mathrm{~b}$, the cesium doping slightly increases the binding energy of $\mathrm{Pb}_{4} \mathrm{f}_{5 / 2}$ from 137.24 to $137.86 \mathrm{eV}$. For I, the $3 \mathrm{~d} 5 / 2$ peak is also blue-shifted by the cesium doping from 618.16 to $618.8 \mathrm{eV}$, as shown in Figure $5 \mathrm{c}$. We speculate that the doped cesium atoms cause local distortion in the lattice, which may affect the binding energies of the $\mathrm{Pb}$ and I ions.
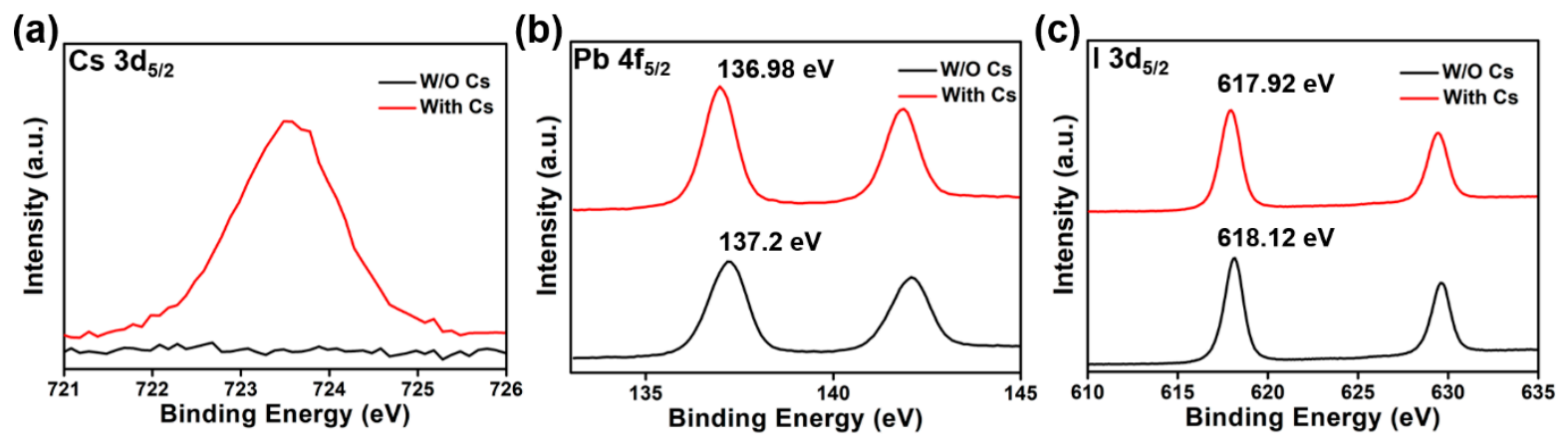

Figure 5. X-ray photoelectron spectroscopy (XPS) results for perovskite films without and with 5\% cesium doping: (a) Cs $3 \mathrm{~d}_{5 / 2}$, (b) $\mathrm{Pb} 4 \mathrm{f}_{5 / 2}$, and (c) $\mathrm{I} 3 \mathrm{~d}_{5 / 2}$.

Our results demonstrate that $\mathrm{Cs}$ doping is effective for improving the crystallinity and morphology of $\mathrm{Pb}(\mathrm{Ac})_{2}$-based perovskite layers, suppressing the formation of secondary phases such as $\mathrm{PbI}_{2}$. Thus, $\mathrm{Cs}$ doping is promising for enhancing the PCEs of $\mathrm{Pb}(\mathrm{Ac})_{2}$-based PSCs by improving the quality of perovskite films.

\section{Summary}

In this study, it is proved that suitable amounts of cesium can improve the film morphology and crystallinity of $\mathrm{Pb}(\mathrm{Ac})_{2}$-based perovskite films and adjust the electrical properties of the photoactive layer of perovskite for extracting more charge. PSCs based on these $\mathrm{Pb}(\mathrm{Ac})_{2}$-based perovskite films were demonstrated with a $\mathrm{PCE}, \mathrm{V}_{\mathrm{oc}}, \mathrm{J}_{\mathrm{sc}}$, and FF of $15.57 \%, 0.98 \mathrm{~V}, 21.08 \mathrm{~mA} \cdot \mathrm{cm}^{-2}$, and 0.75 , respectively. Additionally, the optimized devices showed negligible hysteresis in the forward and reverse J-V scans. This research shows that a perovskite precursor based on lead acetate is a promising source to achieve highly efficient PSCs, and further improvements will be possible through subtle tuning of the chemical composition.

Supplementary Materials: The following are available online at https:/ /www.mdpi.com/1996-194 4/14/2/363/s1, Figure S1: Reverse scan and forward scan J-V curve of 5\% Cs-doping device; Figure S2: Tapping-mode AFM height images of (a) the pristine and (b) Cs-doped perovskite films.; Table S1: Fitted values of the equivalent circuit parameters from dark Nyquist plots of devices without and with $5 \%$ Cs. 
Author Contributions: Conceptualization, Z.L.; Formal analysis, X.L.; Investigation, M.-S.H.; Supervision, E.-C.L.; Visualization, J.Y.; Writing—original draft, M.-S.H., Z.L., X.L. and J.Y.; Writing-review \& editing, E.-C.L. All authors have read and agreed to the published version of the manuscript.

Funding: This work was supported by the National Research Foundation of Korea (NRF) funded by the Ministry of Science and ICT (Grant No. NRF-2016R1A2B2015389) and the Gachon University research fund of 2019 (Grant No. GCU-2019-0350).

Data Availability Statement: Data sharing is not applicable to this article.

Conflicts of Interest: The authors declare no conflict of interest.

\section{References}

1. Stranks, S.D.; Eperon, G.E.; Grancini, G.; Menelaou, C.; Alcocer, M.J.; Leijtens, T.; Herz, L.M.; Petrozza, A.; Snaith, H.J. Electronhole diffusion lengths exceeding 1 micrometer in an organometal trihalide perovskite absorber. Science 2013, 342, 341-344. [CrossRef] [PubMed]

2. Kojima, A.; Teshima, K.; Shirai, Y.; Miyasaka, T. Organometal Halide Perovskites as Visible-Light Sensitizers for Photovoltaic Cells. J. Am. Chem. Soc. 2009, 131, 6050-6051. [CrossRef] [PubMed]

3. Burschka, J.; Pellet, N.; Moon, S.J.; Humphry-Baker, R.; Gao, P.; Nazeeruddin, M.K.; Gratzel, M. Sequential deposition as a route to high-performance perovskite-sensitized solar cells. Nature 2013, 499, 316-319. [CrossRef] [PubMed]

4. Zhou, H.; Chen, Q.; Li, G.; Luo, S.; Song, T.B.; Duan, H.S.; Hong, Z.; You, J.; Liu, Y.; Yang, Y. Photovoltaics. Interface engineering of highly efficient perovskite solar cells. Science 2014, 345, 542-546. [CrossRef] [PubMed]

5. Jeon, N.J.; Noh, J.H.; Yang, W.S.; Kim, Y.C.; Ryu, S.; Seo, J.; Seok, S.I. Compositional engineering of perovskite materials for high-performance solar cells. Nature 2015, 517, 476-480. [CrossRef] [PubMed]

6. Bi, D.; Yi, C.; Luo, J.; Décoppet, J.-D.; Zhang, F.; Zakeeruddin, S.M.; Li, X.; Hagfeldt, A.; Grätzel, M. Polymer-templated nucleation and crystal growth of perovskite films for solar cells with efficiency greater than 21\%. Nat. Energy. 2016, 1, 16142. [CrossRef]

7. Sahli, F.; Werner, J.; Kamino, B.A.; Brauninger, M.; Monnard, R.; Paviet-Salomon, B.; Barraud, L.; Ding, L.; Diaz Leon, J.J.; Sacchetto, D.; et al. Fully textured monolithic perovskite/silicon tandem solar cells with $25.2 \%$ power conversion efficiency. Nat Mater 2018, 17, 820-826. [CrossRef]

8. NREL. Best Research-Cell Efficiency Chart / Photovoltaic Research I NREL. 2019. Available online: https://www.nrel.gov/pv/ cell-efficiency.html (accessed on 13 January 2021).

9. Kim, H.-S.; Lee, C.-R.; Im, J.-H.; Lee, K.-B.; Moehl, T.; Marchioro, A.; Moon, S.-J.; Humphry-Baker, R.; Yum, J.-H.; Moser, J.E. Lead iodide perovskite sensitized all-solid-state submicron thin film mesoscopic solar cell with efficiency exceeding $9 \%$. Scientific reports 2012, 2, 1-7. [CrossRef]

10. Paek, S.; Schouwink, P.; Athanasopoulou, E.N.; Cho, K.T.; Grancini, G.; Lee, Y.; Zhang, Y.; Stellacci, F.; Nazeeruddin, M.K.; Gao, P. From nano- to micrometer scale: The role of antisolvent treatment on high performance perovskite solar cells. Chem. Mater. 2017, 29, 3490-3498. [CrossRef]

11. Tavakoli, M.M.; Yadav, P.; Prochowicz, D.; Sponseller, M.; Osherov, A.; Bulović, V.; Kong, J. Controllable perovskite crystallization via antisolvent technique using chloride additives for highly efficient planar perovskite solar cells. Adv. Energy Mater. 2019, 9, 1803587. [CrossRef]

12. Pool, V.L.; Gold-Parker, A.; McGehee, M.D.; Toney, M.F. Chlorine in $\mathrm{PbCl}_{2}$-derived hybrid-perovskite solar absorbers. Chem. Mater. 2015, 27, 7240-7243. [CrossRef]

13. Zhang, W.; Saliba, M.; Moore, D.T.; Pathak, S.K.; Hörantner, M.T.; Stergiopoulos, T.; Stranks, S.D.; Eperon, G.E.; AlexanderWebber, J.A.; Abate, A.; et al. Ultrasmooth organic-inorganic perovskite thin-film formation and crystallization for efficient planar heterojunction solar cells. Nat. Commun. 2015, 6, 1-10.

14. Zhang, F.; Zhu, K. Additive engineering for efficient and stable perovskite solar cells. Adv. Energy Mater. 2020, 10, 1902579. [CrossRef]

15. Liu, Y.; Liu, Z.; Lee, E.-C. Dimethyl-sulfoxide-assisted improvement in the crystallization of lead-acetate-based perovskites for high-performance solar cells. J. Mater. Chem. C 2018, 6, 6705-6713. [CrossRef]

16. Saliba, M.; Matsui, T.; Seo, J.-Y.; Domanski, K.; Correa-Baena, J.-P.; Nazeeruddin, M.K.; Zakeeruddin, S.M.; Tress, W.; Abate, A.; Hagfeldt, A.; et al. Cesium-containing triple cation perovskite solar cells: Improved stability, reproducibility and high efficiency. Energy Environ. Sci. 2016, 9, 1989-1997. [CrossRef] [PubMed]

17. Nemnes, G.A.; Besleaga, C.; Tomulescu, A.G.; Palici, A.; Pintilie, L.; Manolescu, A.; Pintilie, I. How measurement protocols influence the dynamic JV characteristics of perovskite solar cells: Theory and experiment. Sol. Energy 2018, 173, 976-983. [CrossRef]

18. Liu, W.; Liu, N.; Ji, S.; Hua, H.; Ma, Y.; Hu, R.; Zhang, J.; Chu, L.; Li, X.; Huang, W. Perfection of perovskite grain boundary passivation by rhodium incorporation for efficient and stable solar cells. Nano-Micro Lett. 2020, 12, 119. [CrossRef]

19. Li, S.-S.; Chang, C.-H.; Wang, Y.-C.; Lin, C.-W.; Wang, D.-Y.; Lin, J.-C.; Chen, C.-C.; Sheu, H.-S.; Chia, H.-C.; Wu, W.-R.; et al. Intermixing-seeded growth for high-performance planar heterojunction perovskite solar cells assisted by precursor-capped nanoparticles. Energy Environ. Sci. 2016, 9, 1282-1289. [CrossRef] 
20. Sewvandi, G.A.; Hu, D.; Chen, C.; Ma, H.; Kusunose, T.; Tanaka, Y.; Nakanishi, S.; Feng, Q. Antiferroelectric-to-ferroelectric switching in $\mathrm{CH}_{3} \mathrm{NH}_{3} \mathrm{PbI}_{3}$ perovskite and its potential role in effective charge separation in perovskite solar cells. Phys. Rev. Appl. 2016, 6, 24007. [CrossRef]

21. Gausin, C.M. Improved Thermal Stability of Cesium-Doped Perovskite Films with PMMA for Solar Cell Application. Master's Thesis, Old Dominion University, Norfolk, VA, USA, 2018.

22. Drahansky, M.; Paridah, M.; Moradbak, A.; Mohamed, A.; Owolabi, F.; Asniza, M. We are IntechOpen, the world's leading publisher of Open Access books Built by scientists, for scientists TOP 1\%. Intech 2016, 1, 13.

23. Wu, C.; Guo, D.; Li, P.; Wang, S.; Liu, A.; Wu, F. A study on the effects of mixed organic cations on the structure and properties in lead halide perovskites. Phys. Chem. Chem. Phys. 2020, 22, 3105-3111. [CrossRef]

24. Yang, D.; Zhou, X.; Yang, R.; Yang, Z.; Yu, W.; Wang, X.; Li, C.; Liu, S.; Chang, R.P.H. Surface optimization to eliminate hysteresis for record efficiency planar perovskite solar cells. Energy Environ. Sci. 2016, 9, 3071-3078. [CrossRef]

25. Yang, D.; Yang, R.; Zhang, J.; Yang, Z.; Liu, S.; Li, C. High efficiency flexible perovskite solar cells using superior low temperature $\mathrm{TiO}_{2}$. Energy Environ. Sci. 2015, 8, 3208-3214. [CrossRef]

26. Wang, S.; Zhu, Y.; Wang, C.; Ma, R. Interface modification by a multifunctional ammonium salt for high performance and stable planar perovskite solar cells. J. Mater. Chem. A 2019, 7, 11867-11876. [CrossRef]

27. Gao, W.; Ran, C.; Li, J.; Dong, H.; Jiao, B.; Zhang, L.; Lan, X.; Hou, X.; Wu, Z. Robust Stability of Efficient Lead-Free Formamidinium Tin Iodide Perovskite Solar Cells Realized by Structural Regulation. J. Phys. Chem. Lett. 2018, 9, 6999-7006. [CrossRef]

28. Mahbubur Rahman, M.; Chandra Deb Nath, N.; Lee, J.-J. Electrochemical Impedance Spectroscopic Analysis of SensitizationBased Solar Cells. Isr. J. Chem. 2015, 55, 990-1001. [CrossRef]

29. Yu, J.C.; Hong, J.A.; Jung, E.D.; Kim, D.B.; Baek, S.-M.; Lee, S.; Cho, S.; Park, S.S.; Choi, K.J.; Song, M.H. Highly efficient and stable inverted perovskite solar cell employing PEDOT:GO composite layer as a hole transport layer. Sci. Rep. 2018, 8, 1070. [CrossRef]

30. Pockett, A.; Eperon, G.E.; Sakai, N.; Snaith, H.J.; Peter, L.M.; Cameron, P.J. Microseconds, milliseconds and seconds: Deconvoluting the dynamic behaviour of planar perovskite solar cells. Phys. Chem. Chem. Phys. 2017, 19, 5959-5970. [CrossRef]

31. Zolfaghari, Z.; Hassanabadi, E.; Pitarch-Tena, D.; Yoon, S.J.; Shariatinia, Z.; van de Lagemaat, J.; Luther, J.M.; Mora-Seró, I. Operation mechanism of perovskite quantum dot solar cells probed by impedance spectroscopy. ACS Energy Lett. 2019, 4, 251-258. [CrossRef]

32. Zarazua, I.; Sidhik, S.; Lopéz-Luke, T.; Esparza, D.; De la Rosa, E.; Reyes-Gomez, J.; Mora-Sero, I.; Garcia-Belmonte, G. Operating mechanisms of mesoscopic perovskite solar cells through impedance spectroscopy and J-V modeling. J. Phys. Chem. Lett. 2017, 8, 6073-6079. [CrossRef]

33. Lim, K.-G.; Kim, H.-B.; Jeong, J.; Kim, H.; Kim, J.Y.; Lee, T.-W. Boosting the power conversion efficiency of perovskite solar cells using self-organized polymeric hole extraction layers with high work function. Adv. Mater. 2014, 26, 6461-6466. [CrossRef]

34. Rose, A. Space-charge-limited currents in solids. Phys. Rev. 1955, 97, 1538. [CrossRef]

35. Smith, R.W.; Rose, A. Space-charge-limited currents in single crystals of cadmium sulfide. Phys. Rev. 1955, 97, 1531. [CrossRef]

36. Li, M.; Li, B.; Cao, G.; Tian, J. Monolithic $\mathrm{MAPbI}_{3}$ films for high-efficiency solar cells via coordination and a heat assisted process. J. Mater. Chem. A 2017, 5, 21313-21319. [CrossRef]

37. Liu, Y.; Yang, Z.; Cui, D.; Ren, X.; Sun, J.; Liu, X.; Zhang, J.; Wei, Q.; Fan, H.; Yu, F.; et al. Two-inch-sized perovskite $\mathrm{CH}_{3} \mathrm{NH}_{3} \mathrm{PbX}_{3}$ $(\mathrm{X}=\mathrm{Cl}, \mathrm{Br}, \mathrm{I})$ crystals: Growth and characterization. Adv. Mater. 2015, 27, 5176-5183. [CrossRef]

38. Calloni, A.; Abate, A.; Bussetti, G.; Berti, G.; Yivlialin, R.; Ciccacci, F.; Duo, L. Stability of organic cations in solution-processed $\mathrm{CH}_{3} \mathrm{NH}_{3} \mathrm{PbI}_{3}$ perovskites: Formation of modified surface layers. J. Phys. Chem. C 2015, 119, 21329-21335. [CrossRef] 